\title{
The Influence of Relationship Quality between Manufacturer and Retailer on Future Collaboration-A Case Study of Customer Electronic Product Channel in Taiwan
}

\author{
Shui-Lien Chen ${ }^{1, *} \mathbb{D}$, Hao-Hsiang Tsao ${ }^{1}$ and Yung-Hsin Lee ${ }^{2}$ \\ 1 Department of Management Sciences, Tamkang University, New Taipei City 251301, Taiwan; \\ armand.tsao@gmail.com \\ 2 International Business Department, Tamkang University, New Taipei City 251301, Taiwan; \\ 138332@mail.tku.edu.tw \\ * Correspondence: slchen@mail.tku.edu.tw; Tel.: +886-863-13221
}

check for

updates

Citation: Chen, S.-L.; Tsao, H.-H.;

Lee, Y.-H. The Influence of

Relationship Quality between

Manufacturer and Retailer on Future

Collaboration-A Case Study of

Customer Electronic Product Channel

in Taiwan. Processes 2021, 9, 1045.

https://doi.org/10.3390/pr9061045

Academic Editors: Chih-Te Yang and Chi-Jie Lu

Received: 24 May 2021

Accepted: 13 June 2021

Published: 15 June 2021

Publisher's Note: MDPI stays neutral with regard to jurisdictional claims in published maps and institutional affiliations.

Copyright: (c) 2021 by the authors. Licensee MDPI, Basel, Switzerland. This article is an open access article distributed under the terms and conditions of the Creative Commons Attribution (CC BY) license (https:/ / creativecommons.org/licenses/by/ $4.0 /)$.

\begin{abstract}
This study explores the collaboration between upstream manufacturer brands and first-line retailers in Taiwan's 3C product market, which is influenced by several factors. Both parties are motivated by profit and thus, strive for mutual cooperation in the business environment. Whether influencing factors exist between the retailer and manufacturer is a crucial issue. This study investigates 308 customer electronics retailers in Taiwan. Focusing on relationship quality, relational trust, and retailer satisfaction with the brand, we explore the possibility of future collaboration between retailers and manufacturer brands. The study results indicate the relationship quality between retailers and manufacturers has a significant impact on the relationship of trust. Both the relationship quality between retailers and manufacturers and the relational trust between the retailers and manufacturers have significant impacts on the retailer's satisfaction with the manufacturer. Retailer satisfaction has a direct impact on the future collaboration between retailers and manufacturers. Compared with customers with high expectations, customers with low expectations have a higher effect on the relationship between retailer satisfaction with the brand manufacturer and the future collaboration between retailers and manufacturers.
\end{abstract}

Keywords: relationship quality; relational trust; satisfaction; future collaboration; customer expectation

\section{Introduction}

With the increasing popularity of computer and network applications, 3C products have impacted people's daily lives. Technological advances have enhanced the development of diverse $3 \mathrm{C}$ products to meet customer demands. However, market competition and the enhancement of R\&D and manufacturing capabilities have also generated an excess of supply, which forces most manufacturers to face profit deductions. Therefore, with the flooding of brands, appropriate investments in channel management are a key factor in creating brand competitiveness.

Most product manufacturers expect their products to sell effectively to customers. To complete the process successfully, channel enterprises must rely on critical resources and the complementary capabilities of external partners (e.g., agents, wholesalers, and distributors and retailers) to achieve their goals [1]. These partners are also called marketing channel members.

Taiwan is currently a primary OEM of global IT products, and domestic sales of IT products are increasing annually, further showing that people in Taiwan are heading toward a lifestyle dominated by information technology products. From the past, when only some households owned personal computers and used dial-up Internet connections to the present, wherein almost every person owns a desktop, laptop, or tablet computer, technology products play a significant role in people's daily lives. The survey conducted 
for this study shows that retailers no longer sell only a single product. Instead, it is common to see more than three brands sold in retail locations. How brand manufacturers solidify working relationships with small-scale retailers with less than TWD 9.5 million in monthly revenue and no more than 15 employees to make brands competitive is a particularly significant question. According to the Industry and Technology Intelligence Service (ITIS) project report of the Ministry of Economic Affairs, Taiwan's manufacturers of 3C products are accustomed to using multichannel models to operate their enterprises. They sell their products to customers through agents and wholesalers. Marketing channel members with sales models that use indirect channels focus on maintaining a solid channel relationship. Only when channel members are willing to collaborate with specific brand management can bilateral relations produce value and satisfaction. With the daily increase in familiarity, habit, and reliance, the cost of invested resources will also greatly increase and will increase byproducts in the form of intangible costs and causing retailers to be unable to forsake the sale of products from a specific brand. If combined with deeply loyal support, this will produce a positive attitude toward a specific brand in terms of the loyalty and desire of cooperation from retailers and develop into a long-term sales relationship. This relationship allows channel members to commit to selling that brand's products, and it also allows product manufacturers to maintain advantages in the market.

Previous research on marketing channels has focused on the organization's responsibility toward channel members and the relationship between a firm's management and its channel members [2]. However, few studies have researched the direct relationship between product manufacturers and first-line retailers, despite this relationship being based on interdependence. Moreover, in addition to mutual cooperation, a system of checks and balances also exists in this relationship [3]. Although existing studies have qualitatively focused on the problem of marketing channel management [4], the recent increase in the availability of sales data, how to enhance the channel performance is imperative.

The manufacturers of $3 C$ products need to establish the relationships with retailers who are willing to complete and achieve the goal of product sales and are willing to sell the products of a specific brand over the long term. Retailers value not only profit but also a relationship based on trust and satisfaction with brand manufacturers. Therefore, this study focuses on the relationship quality and mutual trust with retailers from the manufacturer's perspective. Satisfaction with the supplier and other significant factors consequently impact future collaboration between retailers and manufacturers. The results of this study can allow product manufacturers to gain a clear direction for channel management and outline business objectives for a favorable long-term channel.

These issues are investigated empirically, following a literature review and research hypothesis, research model and methodology, data analyses and results, and conclusion. The literature review and research hypothesis present the development of concrete hypotheses based on previous studies for the study's framework. The research model and methodology introduce the relationship constructs to support the hypotheses and elaborates on the data collection process. The data analyses and results provide the analyzed data and the results of the research hypotheses. Finally, the conclusion offers a discussion on the findings related to the research.

\section{Literature Review and Research Hypothesis}

\subsection{Literature Review}

\subsubsection{Relationship Quality}

Relationship quality refers to customers' perceptions and evaluations of relationship performance with a company fulfilling their demands and anticipations [5]. Scholars and practitioners agree that building a close relationship with key partners is a critical strategy for promoting a long-term business relationship. Channel relationships likely influence future cooperation between the retailer (the downstream partner) and the manufacturer (the upstream partner). Satisfaction and trust between cooperating partners were influenced by the quality of their relationship [6]. 
All channel partners expect a long and stable relationship in their channel business when they trust each other with good relationship quality in a major business deal [7]. Channel partners can benefit from a long-term relationship, and these benefits might be a company's approval of and adherence to the specific requirements and policies of its partner [7]. Therefore, relationship quality significantly influences the customer's word of mouth [8] and possible exemption from future commitments [9].

Mutual trust between retailers and manufacturers may establish a good relationship quality. Despite the firm's reliance on the support of the manufacturer, the manufacturer must nevertheless monitor its partners. If a good relationship exists between a firm and a manufacturer, the manufacturer can reduce monitoring costs and increase sales. Therefore, high-quality partnerships ensure that problems are easier to solve, and they improve economic outcomes. The company's supply chain relationship quality (SCRQ) is a crucial topic that deserves further attention [10].

\subsubsection{Relational Trust}

Trust has been defined as someone's willingness to rely on an exchange partner in whom one has confidence [11]. The authors of [11] defined customer trust as the willingness and confidence to count on an exchange partner, which reflects a consistent readiness to become involved in a relationship with the other party. Customer trust is a psychological assertion that evokes customers to accept object vulnerability based on expectations concerning behavioral intention. Therefore, relational trust is gained over time, linking to expectancy to resolve customers' hesitant behavior [12].

When transactions are conducted repeatedly, decision -makers often lack concern for other opportunities and are more willing to engage in open communication and show greater transparency. For the establishment of trust between businesses, decision-makers are engaged in a low-risk business [13] and satisfaction perception [14]. If the manufacturer must monitor retailers by asking them to fulfill their obligations and guarding against opportunism, it incurs various costs for such vigilance [15]. Moreover, if a manufacturer does not have a positive attitude toward its product, retailers also face negative product sales. Instead, if companies nurture a healthy relationship quality to support their mutual trust, they can plan for long-term cooperation and business development and increase their mutual trust and decrease transaction costs in the exchange process [7].

\subsubsection{Retailer's Satisfaction with the Manufacturer}

Satisfaction is the feeling generated by both perceptions and emotional attitudes toward products and services, as well as by an accumulated evaluation of various components and features. Many theories and explanatory models focus on perception and emotional attitude as factors that influence satisfaction. The author of [16] indicated that "satisfaction is a function of disconfirmation and disconfirmation is a function of expectations and of fulfillment." Confirmation and disconfirmation theory recognize that satisfaction is obtained when expectations are fulfilled and that the negative disconfirmation of expectations results in dissatisfaction, whereas positive disconfirmation increases satisfaction.

Satisfaction has been widely debated in marketing literature [17] despite the absence of a clear consensus regarding what the determinant variables are. Most previous studies have focused on assessing customer expectations, quality cognition, and perceived satisfaction. The trend over the last few years shows that customers consider these factors and that customer emotions have also become an important factor in the perception of satisfaction [18].

\subsubsection{Future Collaboration}

Collaboration has been defined as a relational system in the common pool of resources; every member can use these resources to facilitate group or individual goals and was noted to be a key element of effective service, and it reduces the costs of entering the market and obtaining technological knowledge [19]. Empirical research indicates that 
collaboration between partners is affected by the performance between focal firms and their manufacturers. Between inter-firms, collaboration can be defined as "a process in which organizations exchange information, alter activities, share resources, and enhance each other's capacity for mutual benefit and a common purpose by sharing risks, responsibilities, and rewards" [19]. Collaboration among partners is critical to achieving common goals [7]. According to these studies, manufacturers are increasingly engaging in value-enhancing collective efforts, such as the exchange of best practices, joint product development, and adjusting marketing strategies to increase market shares.

Some theorists believe that collaboration is obviously superior to individual action for achieving virtually all goals $[20,21]$. Collaboration between partners in strategic alliance is a significant concept because it represents a paradoxical situation [22]. Brand manufacturers are supposed to pursue their own interests; however, most $3 \mathrm{C}$ retailers sell more than one product brand in their stores. Manufacturer brands must therefore restrain this natural pursuit from making the alliance work. The key is to strike a balance between competition and cooperation. Collaboration between firms occurs in complex multidimensional contexts with several interacting factors that influence the development of collaboration. Some studies have assessed model projects of inter-firm collaboration in human-service delivery systems. The overall results show the effectiveness of these efforts. Positive results include the growth of interagency linkages, diverse inter-firm activities, and an increased sense of collective power among members, positive attitudes, and increased information and referral exchange [23,24].

\subsubsection{Customer Expectations}

Customer expectations can be defined as the "perceived potential of alternative manufacturers and brands to satisfy a number of explicit and implicit objectives in any particular buying decision" [25]. The authors of [26] also noted that customer expectations are beliefs toward product performance, quality of service as a judge of the standard, and reference points. Expectations, therefore, express a conscious construct [27], indicating the beliefs of individual customers toward products and manufacturers based on the result of their trust perception [28]. In the customer market, the mentality is formed by not only information processing but also factors related to the customer's background, such as working conditions, living habits, educational level and gender, and by their satisfaction with previous buying experiences $[25,27]$.

Service is also a crucial factor that affects the degree of customer expectation of products. There is no reason to suppose that national culture exerts a significant influence on the formation of service quality expectations, certainly not more so than the customer's previous buying experiences [29]. Customers also compare their expectations with the actual quality of service performance [30]. Many questions related to the role of expectation in service evaluation remain.

\subsection{Research Hypothesis}

\subsubsection{Relationship Quality and the Relational Trust}

A solid relationship between the retailer and manufacturer is critical to market success; however, this relationship is usually developed gradually. Therefore, building a close and healthy relationship with key partners is an important marketing strategy for obtaining a strong and long-term business relationship. Channel relationships likely influence future cooperation between a retailer (the downstream partner) and manufacturer (the upstream partner). The authors of [31] found that there was a strong correlation between relationship quality and relational trust. Relational trust will be affected by the relationship quality between retailers and suppliers [6]. The relationship between the retailer and manufacturer should gradually strengthen as investments accumulate over time. Therefore, based on these descriptions, the following hypothesis is established: 
Hypothesis 1 (H1). Retailer and manufacturer relationship quality has a positive impact on relational trust.

\subsubsection{Relational Trust and Retailer's Satisfaction with Brand Manufacturer}

Trust between manufacturers and retailers can affect the relational satisfaction between two parties. Previous research emphasized the significance of trust as a cumulative variable that affects the partner's satisfaction [32]. Satisfaction represents the overall feeling between a company and its partners [33], and relational trust enhances a satisfactory relationship or the feeling of "confidence in an exchange partner's reliability and completeness" [7]. When trust is built through repeated transactions, corporate decision-makers tend to be less concerned with the opportunistic behavior of others [13]. Therefore, trust is significantly related to customer satisfaction [34]. Mutual trust produces a higher level of satisfaction between manufacturers and retailers. Hence, the following hypothesis is offered:

Hypothesis 2 (H2). Relational trust has a positive impact on the retailer's satisfaction with the brand manufacturer.

\subsubsection{Relationship Quality and Retailer's Satisfaction with the Manufacturer}

A high-quality relationship must exist, and between retailers and manufacturers, this argument is consistent with the empirical evidence demonstrating that the relationship quality is an antecedent of satisfaction. Therefore, both facets of relationship quality and relational trust-should increase the retailer's satisfaction with the manufacturer. The retailer's satisfaction with the manufacturer must be based on their relationship quality, in order to produce higher satisfaction, higher relationship quality must be obtained and represented by satisfaction enhancement $[35,36]$. According to this description, the following hypothesis is established:

Hypothesis 3 (H3). Retailer and manufacturer relationship quality has a positive impact on the retailer's satisfaction with the brand manufacturer.

\subsubsection{Retailer's Satisfaction with the Manufacturer and Future Collaboration}

The retailer must experience sufficient satisfaction with the brand manufacturer to enter into future collaborations. The company's satisfaction influences the future of the relationship and the collaboration [16]. Current experiences are expected to recur in future collaborations. Therefore, inter-firm collaborations continue only if the project experiences meet each company's expectations [33]. They are more willing to engage in open communication and show greater behavioral clarity toward retailers. If a manufacturer cannot convince the majority of retailers to sell its products, then it loses the market. If satisfaction is flawed, they cannot plan for a future long-term cooperative relationship. There is a direct link between satisfaction and future collaboration [37]. Therefore, the following hypothesis is established:

Hypothesis 4 (H4). The retailer's satisfaction with the manufacturer has a positive impact on future collaboration.

\subsubsection{Relational Trust and Future Collaboration}

Relational trust is a crucial indicator in relationship models between buyers and sellers [6]. In contemporary marketing theory, increasingly more attention is given to the practice of close long-term cooperative relationships. Relational trust plays a critical role in customers' anticipation about their behavior over the long term [12]. Previous studies have revealed the direct link between trust and future collaboration [7]. Therefore, the following hypothesis is established:

Hypothesis 5 (H5). The relational trust has a positive impact on future collaboration. 
2.2.6. Moderating Effect of Customer Expectation between Retailer's Satisfaction with the Manufacturer and Future Collaboration

According to [38], "Customer expectations refers to whether retailers thought customers expected the brand to be available and customer concerns if that brand was not available in-store." Retailers are concerned with profit. A popular product leads to high sales volumes, which result in higher profits for the company. In this study, customer expectation is used as a moderating variable that impacts the relationship between a retailer's satisfaction with the manufacturer and future collaboration. The higher the customer expectation, the higher the probability to increase product sales. High sales can increase retailers' profits and their satisfaction, which can increase willingness to cooperate with the manufactures in the future. Therefore, the following hypothesis is offered:

Hypothesis 6 (H6). The higher the customer expectation, the stronger the positive effect between the retailer's satisfaction with brand supplier and future collaboration.

\section{Research Model and Methodology}

\subsection{Research Framework}

The relationship between the construct models investigated in this chapter is in accordance with prior literary reviews. Figure 1 shows the conceptual framework of this research.

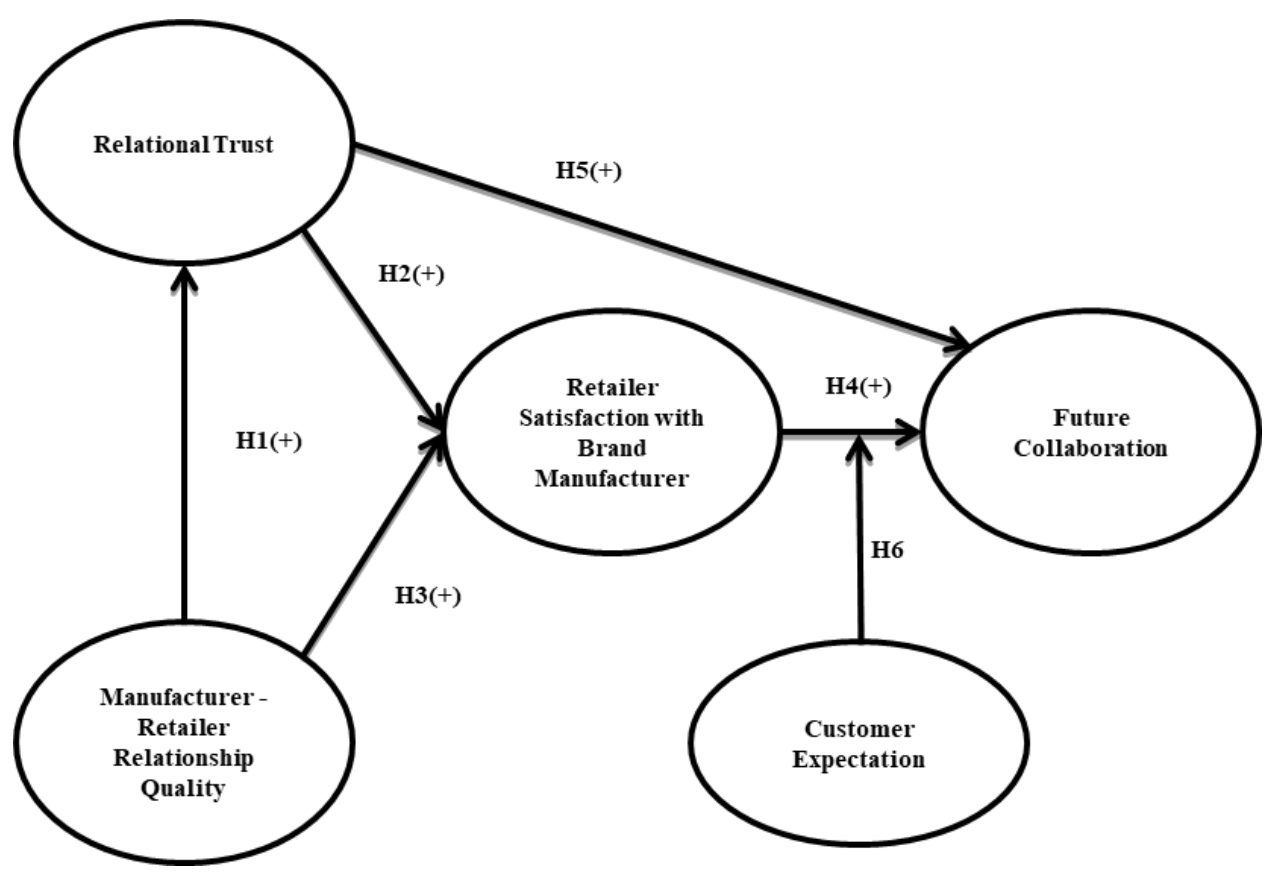

Figure 1. Conceptual framework of research.

\subsection{Sample and Data Collection}

The empirical study used to test the proposed hypotheses is based on information collected from questionnaires presented to first-line 3C-product retailers located in Taiwan's north, central and southern cities. A total of 308 valid data were collected for the analysis. This questionnaire, we specified to be completed by the company's decision-makers, these are owner, executive, and supervisor. To test non-response bias, we compared the two sets of responses with all response items for each scale. No significant difference between the two groups was found. 


\subsection{Questionnaire Design}

The questionnaire design was relatively straightforward. First, this study developed the questions by following previous studies. Table 1 presents a summary of the corresponding literary sources for the measured items.

Table 1. Sources of the measure items.

\begin{tabular}{|c|c|c|}
\hline Construct & Items & Literary Source \\
\hline $\begin{array}{l}\text { Retailer-Manufacturer } \\
\text { Relationship Quality }\end{array}$ & $\begin{array}{l}\text { - A strong spirit of fairness exists between } \\
\text { retailer and manufacturer. } \\
\text { There is a high level of trust between } \\
\text { retailer and manufacturer. } \\
\text { - We usually get a fair share of the rewards in our } \\
\text { relationships with the terminal operator. }\end{array}$ & [39] \\
\hline Relational Trust & $\begin{array}{l}\text { When making important decisions, supplier } X \text { considered } \\
\text { our welfare as well as its own. } \\
\text { - We trust supplier } X \text { keeps our best interests in mind. } \\
\text { - Supplier X was trustworthy. }\end{array}$ & [33] \\
\hline $\begin{array}{l}\text { Retailer Satisfaction with Brand } \\
\text { Manufacturer }\end{array}$ & $\begin{array}{l}\text { - Overall, we are very satisfied with this supplier. } \\
\text { - } \quad \text { We are very pleased with what this supplier does for us. } \\
\text { - } \quad \text { If we had to do it all over again, we would still choose to } \\
\text { use this supplier. }\end{array}$ & [40] \\
\hline Customer Expectations & $\begin{array}{l}\text { - } \quad \text { Expect brand in-store. } \\
\text { - } \quad \text { Concern if brand not in range. } \\
\text { - Complain if brand not there. }\end{array}$ & [41] \\
\hline Future Collaboration & $\begin{array}{l}\text { - Welcome the possibility of future collaboration with } \\
\text { supplier } X \text { in additional projects. } \\
\text { - } \quad \text { Be willing to work with supplier } X \text { in projects in the future. } \\
\text { Be willing to collaborate with supplier } X \text { in projects, } \\
\text { should the opportunity arise. }\end{array}$ & [33] \\
\hline
\end{tabular}

This study then used pretests to eliminate ambiguity and strengthen the clarity and completeness of the questionnaire and its scales by incorporating suggestions. Because the investigation was conducted in Taiwan, the scales were translated into Chinese. All scales in Chinese were then back-translated and compared to the original to ensure translation equivalence, satisfying fundamental cross-cultural validation issues. Finally, each 7-point Likert scale in the questionnaire was anchored from 1 (strongly disagree) to 7 (strongly agree).

\subsection{Common Method Bias}

Cross-sectional studies related to the relationship between attitude and behavior are easily affected by the inflation of correlations by common method variance bias (CMB) [42,43]. CMB usually happens when a study uses a single self-reporting questionnaire to measure multi-constructs [44]. One-factor testing was the technique frequently employed to check the CMB problem [45]. CFAs were used to test the difference between the single-factor and multifactor model by comparing the $\chi^{2} / d f$ and the significance to determine whether the CMB exists. The single-factor model yielded $\chi^{2}=1031.273$ with 65 degrees of freedom $\left(\chi^{2} / d f=15.866\right)$. This model provided a significantly worse fit to the data $(p<0.001)$ than the four-factor measurement model with $\chi^{2}=216.739$ with 59 degrees of freedom $\left(\chi^{2} / d f=3.67\right)$. Thus, there is a significant difference between the two models, and the results suggested there is no CMB problem in this study. 


\subsection{Data Analysis Method}

To empirically analyze the collected data and examine the hypotheses, we used several statistical analyses.

\subsection{Descriptive Statistics Analysis}

We provide fundamental characteristics of the respondents. The goal was to understand the subjects of each variable in the study, the concentration of the total sample presented with discrete cases, and to realize every aspect of the variables in different samples. These variables include gender, age, education, job type, and job level.

\subsection{Reliability and Validity of the Measurement}

First, this study includes reference indices to explicate the model fit, which includes goodness of fit (GFI), comparative fit index (CFI), chi-square model, normed fit index (NFI), adjusted goodness of fit index, standard root mean square residual (SRMSR), and root mean square error of approximation (RMSEA).

Estimation of measurement reliability and validity depends on a confirmatory factor analysis (CFA) that contains all multi-item constructs in the framework. The reliability of measurements is obtained in three ways; (a) to measure by composite reliability (CR), the value of which should exceed 0.6 [46]; (b) to test Cronbach's alpha value, of which 0.7 is the acceptable level [47]; and (c) in accordance with [36], all items with a factor loading greater than 0.5 are considered significant.

The validity of a construct is tested using two methods: discriminant validity and convergent validity. In relation to discriminant validity, the measure of average variance extracted (AVE) was applied to access the discriminant validity of the measurement [48]. Regarding convergent validity, the AVE of a construct must be greater than 0.5 to satisfy the convergent validity of constructs. Moreover, all factor loadings of items are significant, that is, $t$-values exceed 1.96 [48]. To meet the discriminative validity request, the AVE square root of the construct must be greater than the correlation between the constructs. Second, the differential validity of measures was also assessed by examining the confidence interval ( \pm two standard errors) of the correlation estimate of two constructs. If this confidence interval does not contain \pm 1 , then it shows that these two constructs are unequal [49].

\subsection{Structural Equation Model}

After completing the measurement model test with reliability and construct validity analysis, AMOS 17.0 was used to examine the structural equation model (SEM) and CFA, testing the hypotheses for the construct relationships. Moreover, using reference indices to illustrate the fit of the SEM, these indices include the GFI, chi-square, standard root mean square (SRMR), adjusted goodness of fit (AGFI), TLI, RMSEA, and CFI.

\section{Data Analysis and Results}

This study used AMOS 17.0 to examine the collected data. This chapter is divided into the following three parts: (a) sampling and respondent profile to represent the sample structure; (b) validity and reliability analysis of the results; and (c) hypothesis test results using SEM analysis.

\subsection{Respondent Profiles}

Among the 308 valid respondents, 188 were male (61\%), and 120 were female (39\%). Most respondents (79.9\%) were between 20 and 39 years of age. A total of $93.2 \%$ of the respondents had a college/university degree or higher. Regarding job type, approximately $56.5 \%$ worked in sales, with the majority at the general level $(47.7 \%)$. Detailed descriptive statistics relating to the respondents' profiles are shown in Table 2.

For the respondents' company profile, most companies in the sample specialized in computer accessories with existing branch stores, but without branch store opening 
exception in the future. Approximately $21.1 \%$ of the companies earned a total monthly income of TWD 1.1 million to 3.5 million (Table 3).

Table 2. Descriptive statistics of the respondents' profiles.

\begin{tabular}{|c|c|c|c|c|c|}
\hline Gender & Freq. & $\%$ & Education & Freq. & $\%$ \\
\hline Male & 188 & 61 & $<=$ Senior high school & 21 & 6.8 \\
\hline Female & 120 & 39 & College & 98 & 31.8 \\
\hline Age & Freq. & $\%$ & University & 149 & 48.4 \\
\hline $20-29$ & 100 & 32.5 & $>=$ Graduate & 40 & 13 \\
\hline $30-39$ & 146 & 47.4 & Job Levels & Freq. & $\%$ \\
\hline $40-49$ & 51 & 16.6 & Owner & 96 & 31.2 \\
\hline \multirow[t]{2}{*}{$50-59$} & 11 & 3.5 & Executive & 89 & 28.9 \\
\hline & & & Supervisor & 123 & 39.9 \\
\hline
\end{tabular}

Table 3. Descriptive statistics of the respondents' company profiles.

\begin{tabular}{|c|c|c|c|c|c|}
\hline Main Products Sold & Freq. & $\%$ & Expected to Open a Branch Store & Freq. & $\%$ \\
\hline Desktop PC & 203 & 26.8 & Yes & 140 & 45.5 \\
\hline Notebook & 290 & 38.2 & No & 168 & 54.5 \\
\hline Computer Accessories & 262 & 34.5 & Monthly Income (TWD) & Freq. & $\%$ \\
\hline Other & 4 & 0.5 & $<=1$ Million & 29 & 9.4 \\
\hline Branch Store & & & 1.1-3.5 Million & 65 & 21.1 \\
\hline Yes & 219 & 71.1 & 3.51-6.5 Million & 45 & 14.6 \\
\hline No & 89 & 28.9 & 6.51-9.5 Million & 48 & 15.6 \\
\hline Quantity of Store & Freq. & $\%$ & 9.51-13 Million & 38 & 12.3 \\
\hline$<=1$ & 89 & 28.9 & 13.01-17 Million & 26 & 8.4 \\
\hline 2 & 80 & 26 & 17.01-22 Million & 10 & 3.2 \\
\hline 3 & 39 & 12.7 & 22.01-30 Million & 16 & 5.2 \\
\hline 4 & 20 & 6.5 & $>=30.01$ Million & 31 & 10. \\
\hline 5 & 13 & 4.2 & & & \\
\hline$>=6$ & 67 & 21.7 & & & \\
\hline
\end{tabular}

\subsection{Measurement Model Results}

\subsubsection{CFA and Model Fit}

We conducted CFA to verify the accuracy of the scales in a supply-chain context. A chi-square/ $d f$ less than 5.0, the GFI, adjusted normed fit index (NFI), and the CFI greater than 0.9 , and an SRMR less than 0.06 were cutoffs that indicated a model fit [50]. The AGFI should be greater than 0.8 [34,46]. The RMSEA should be less than 0.1 . In this study, the CFA model had an overall chi-square/ $d f$ of 3.67 , a GFI of 0.90 , an AGFI of 0.85 , a CFI of 0.95 , an NFI of 0.93, an RMSEA of 0.09, and an SRMR of 0.06. All of these values were above the thresholds recommended in the literature. Thus, the fit of the model is acceptable (Table 4).

\subsubsection{Reliability Analysis}

The reliability test examined individual reliability in one way and construct reliability in two ways. Individual reliability examines each item by evaluating the factor loadings with their respective constructs. The authors of [50] indicated that all items of factor loadings should exceed 0.5. As shown in Table 5, all measured items have factor loadings above 0.50 . Therefore, the results show evidence of individual reliability. Composite reliability (CR) and Cronbach's $\alpha$ were used to examine construct reliability. According to [46], the CR value should exceed 0.6 for potential questionnaire items to be consistent and [47] indicated that Cronbach's $\alpha$ value should exceed 0.7. All items in the measurement model of this 
study show CR and alpha values ranging between a low 0.83 for "relational trust" and a high 0.91 for "retailer satisfaction with the brand manufacturer" and "future collaboration" (Table 5), which shows that the construct reliability indicators fell within acceptable ranges. Therefore, the results in this study provide evidence of acceptable reliability.

Table 4. CFA model fits.

\begin{tabular}{cccc}
\hline Index Name & Criterion Value & Index Value of the Model & Indicator \\
\hline$\chi^{2} / d f$ & $<5$ & $3.67^{*}$ & {$[50]$} \\
\hline GFI & $>0.9$ & $0.90^{*}$ & {$[46]$} \\
\hline AGFI & $>0.8$ & $0.85^{*}$ & {$[50]$} \\
\hline CFI & $>0.9$ & $0.95^{*}$ & $0.93^{*}$ \\
\hline NFI & $>0.9$ & $0.06^{*}$ & {$[51]$} \\
\hline SRMSR & $<0.06$ & $0.09^{*}$ & \\
\hline RMSEA & $<0.1$ & &
\end{tabular}

Table 5. Measurement properties.

\begin{tabular}{|c|c|c|c|c|c|c|}
\hline Construct & Item & $\begin{array}{c}\text { Factor } \\
\text { Loading }\end{array}$ & $t$-Value & CR & Cronbach's $\alpha$ & AVE \\
\hline \multirow{3}{*}{ MRRQ } & 3 & 0.90 * & 20.86 & \multirow{3}{*}{0.89} & \multirow{3}{*}{0.89} & \multirow{3}{*}{0.73} \\
\hline & & 0.72 * & 15.71 & & & \\
\hline & & $0.87^{*}$ & 19.92 & & & \\
\hline \multirow{3}{*}{ RT } & 3 & $0.82 *$ & 16.71 & \multirow{3}{*}{0.84} & \multirow{3}{*}{0.83} & \multirow{3}{*}{0.64} \\
\hline & & $0.86^{*}$ & 17.70 & & & \\
\hline & & $0.62 *$ & 12.35 & & & \\
\hline \multirow{4}{*}{ RSBM } & 4 & 0.86 * & 20.41 & \multirow{4}{*}{0.91} & \multirow{4}{*}{0.91} & \multirow{4}{*}{0.71} \\
\hline & & $0.85 *$ & 20.02 & & & \\
\hline & & 0.83 * & 19.39 & & & \\
\hline & & $0.73 *$ & 16.00 & & & \\
\hline \multirow{3}{*}{ FC } & 3 & 0.77 * & 17.81 & \multirow{3}{*}{0.91} & \multirow{3}{*}{0.91} & \multirow{3}{*}{0.78} \\
\hline & & $0.97 *$ & 24.68 & & & \\
\hline & & 0.89 * & 21.69 & & & \\
\hline
\end{tabular}

*: $p<0.001$; MRRQ: manufacturer-retailer relationship quality; RT: relationship trust; RSBM: retailer satisfaction with brand manufacturer; FC: future collaboration.

\subsubsection{Validity Analysis}

The validity test was divided into convergent validity and discriminant validity. Two key measurements ensure convergent validity that the $t$-value of factor loadings should exceed 1.96 with significance and AVEs should exceed 0.50 [48]. Table 5 shows that all $t$-values of items exceeded 1.96, and all the AVEs of the four constructs exceeded 0.5. Therefore, these two indicators show convergent validity for all of the constructs in this study.

Two methods were used to measure discriminant validity: a variance extracted test as well as the squared correlations and the confidence interval test. First, the variance extracted test means that the construct's AVEs must be greater than the square of the correlation between constructs in the model [48]. The diagonal in Table 6 shows that the construct's AVEs are greater than the square of the correlations between constructs in the model. Second, discriminant validity was assessed by examining the confidence interval in the correlation ( \pm two standard errors) of two constructs. If the confidence interval does not include 1.0, it indicates that the two constructs are unequal and have a significance of discriminant validity [49]. The confidence intervals in the correlation of paired constructs are shown in Table 7, and each pair does not include 1.0, which shows strong evidence of each construct's discriminant validity. Therefore, both discriminant validity indicators fall within acceptable ranges. 
Table 6. Correlation and AVE results.

\begin{tabular}{ccccc}
\hline & MRRQ & RT & RSBM & FC \\
\hline MRRQ & $\mathbf{0 . 7 3}$ & & & \\
RT & 0.53 & $\mathbf{0 . 6 4}$ & & \\
RSBM & 0.53 & 0.74 & $\mathbf{0 . 7 1}$ & $\mathbf{0 . 7 8}$ \\
FC & 0.22 & 0.15 & 0.39 &
\end{tabular}

The cells on the diagonal are AVEs; on the bottom left corner are correlations; MRRQ: manufacturerretailer relationship quality; RT: relationship trust; RSBM: retailer satisfaction with brand manufacturer; FC: future collaboration.

Table 7. Correlation coefficient confidence intervals.

\begin{tabular}{cccc}
\hline & Correlations & S.E. & Confidence Intervals \\
\hline MRRO RT $_{\text {RRR }}$ RSBM $_{\text {RSM }}$ & 0.728 & 0.036 & $(0.728,0.800)$ \\
MRRQ FC $_{\text {FT }}$ RSBM $_{\text {RSM }}$ & 0.729 & 0.034 & $(0.729,0.797)$ \\
FC & 0.465 & 0.050 & $(0.465,0.565)$ \\
RSBM FC $_{\text {F }}$ & 0.648 & 0.041 & $(0.648,0.73)$ \\
\hline
\end{tabular}

\subsection{Structural Model Results}

The SEM was used to examine the path interrelationship between constructs in the conceptual model and overall model validation. Before conducting path analysis, the overall model fit was tested to ensure the SEM model's fitness to the data. Criterion values were introduced in the CFA section. According to the statistics of absolute, incremental, and parsimonious fit measures, each standard index is acceptable for the structural model. Fit indices $\left(\chi^{2} / d f=3.62, \mathrm{GFI}=0.90, \mathrm{AGFI}=0.85, \mathrm{CFI}=0.95, \mathrm{NFI}=0.93, \mathrm{RMSEA}=0.09\right.$, $\mathrm{SRMR}=0.06$ ) show that the final structural model is good because it reproduces the population covariance structure with an acceptable discrepancy between the observed and predicted covariance matrices.

According to SEM analysis, the hypothesis test can be identified in the structural model from the path coefficient between constructs. The path coefficient from the manufacturerretailer relationship quality to relational trust is $0.73(p<0.001)$. Manufacturer-retailer relationship quality is identified as having a significant positive effect on relational trust; hence, H1 is supported. The path coefficients from the manufacturer-retailer relationship quality and relational trust to retailer satisfaction with the brand manufacturer were $0.25(p<0.01)$ and $0.55(p<0.001)$, respectively. Therefore, H2 and H3 are supported, meeting our expectations. The path coefficient from retailer satisfaction with the brand manufacturer to future collaboration is $0.66(p<0.001)$, and the hypothesized positive relationship between retailer satisfaction with the brand manufacturer and future collaboration is supported; thus, H4 is supported. Finally, the path coefficients from the relational trust to future collaboration were not significant $(p>0.05)$; thus, H5 is rejected. To summarize, all the hypotheses were verified except $\mathrm{H} 5$ in this study (Figure 2 and Table 8 ).

In addition, the coefficient of determination, $R^{2}$, is a measurement of the independent variables predicting the dependent variable. Thus, relational trust was effectively predicted by the manufacturer-retailer relationship quality $\left(R^{2}=0.53\right)$, and the manufacturer-retailer relationship quality and relational trust effectively predicted retailer satisfaction with the brand manufacturer $\left(R^{2}=0.56\right)$. Future collaboration was effectively predicted by its antecedent factors $\left(R^{2}=0.40\right)$. 


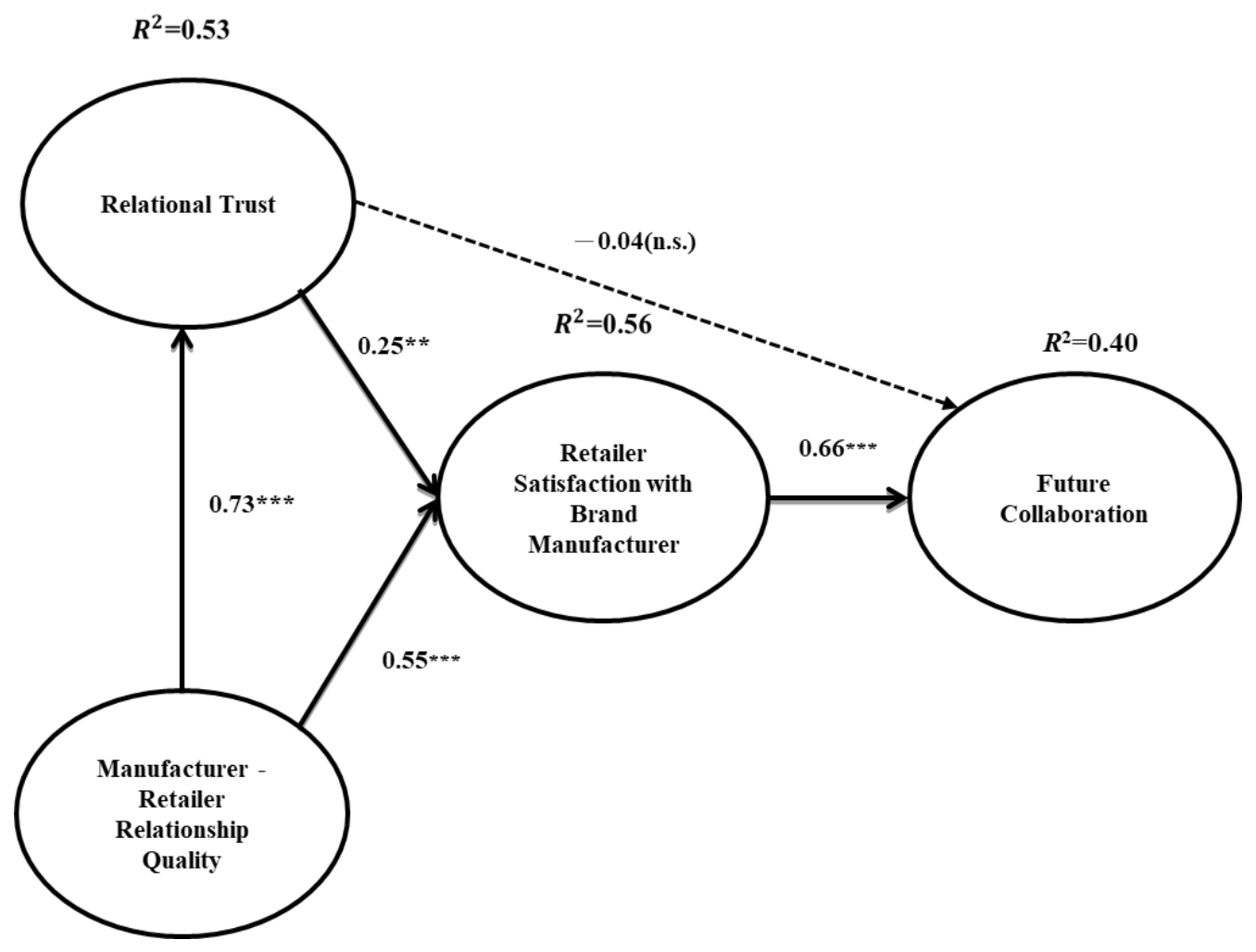

Figure 2. Structural equation model of hypotheses testing result. ${ }^{* *} p<0.01{ }^{* * *} p<0.001$.

Table 8. The results of the structural equation model.

\begin{tabular}{cccc}
\hline Hypothesis & $\begin{array}{c}\text { Proposed } \\
\text { Effect }\end{array}$ & $\begin{array}{c}\text { Path } \\
\text { Coefficient }\end{array}$ & Result \\
\hline H1 MQ $\rightarrow$ RT & + & $0.73^{* * *}$ & supported \\
H2 RT $\rightarrow$ RSBM & + & $0.25^{* *}$ & supported \\
H3 MRRQ $\rightarrow$ RSBM & + & $0.55^{* * *}$ & supported \\
H4 RSBM $\rightarrow$ FC & + & $0.66^{* * *}$ & supported \\
H5 RT $\rightarrow$ FC & + & -0.04 (n.s.) & rejected \\
\hline${ }^{* *} p<0.01 ; * * *<0.001$. & & &
\end{tabular}

\subsection{Mediation Effect of Relationship Trust and Retailer Satisfaction with Brand Manufacturer}

The mediation effect of relationship trust between manufacturer-retailer relationship quality and retailer satisfaction with the brand manufacturer, and retailer satisfaction with brand manufacturer between relationship trust/manufacturer-retailer relationship quality and future collaboration were tested, and results are shown in Table 9.

As a result of bootstrap analysis to determine the mediation role of relationship trust, the direct effect of the manufacturer-retailer relationship quality on retailer satisfaction with the brand manufacturer was shown to be significant $(\beta=0.551 ; t$-value $=6.26)$, and the indirect effect via relationship trust was also significant $(\beta=0.180 ; t$-value $=2.47)$. The findings of the study demonstrate a partial mediation role of relationship trust in the relationship between manufacturer-retailer relationship quality and retailer satisfaction with the brand manufacturer.

It is shown that relationship trust had an indirect effect on future collaboration through retailer satisfaction with brand manufacturer $(\beta=0.162 ; t$-value $=2.38)$. Whereas the direct effect was not significant $(\beta=-0.04 ; t$-value $=-0.44)$. The findings found that retailer satisfaction with the brand manufacturer has full mediation in the relation between relationship trust and future collaboration. This study also revealed manufacturer-retailer relationship quality had a significant indirect effect on future collaboration. 
Table 9. Direct, Indirect, and Total Effects.

\begin{tabular}{|c|c|c|c|c|}
\hline $\begin{array}{c}\text { Path } \\
\text { From } \\
\end{array}$ & To & $\begin{array}{c}\text { Direct Effects } \\
\text { Coeff. ( } t \text {-Value) }\end{array}$ & $\begin{array}{l}\text { Indirect Effects } \\
\text { Coeff. ( } t \text {-Value) }\end{array}$ & $\begin{array}{c}\text { Total Effects } \\
\text { Coeff. }\end{array}$ \\
\hline $\begin{array}{l}\text { Manufacturer-Retailer } \\
\text { Relationship Quality }\end{array}$ & Relationship Trust & $0.728^{* * *}(18.2)$ & & 0.728 \\
\hline $\begin{array}{l}\text { Manufacturer-Retailer } \\
\text { Relationship Quality }\end{array}$ & \multirow{2}{*}{$\begin{array}{c}\text { Retailer Satisfaction } \\
\text { with Brand } \\
\text { Manufacturer }\end{array}$} & $\begin{array}{l}0.551^{* * *} \\
(6.26)\end{array}$ & $\begin{array}{l}0.180 * \\
(2.47)\end{array}$ & 0.731 \\
\hline Relationship Trust & & $\begin{array}{l}0.247 * \\
(2.52)\end{array}$ & & 0.247 \\
\hline $\begin{array}{l}\text { Manufacturer-Retailer } \\
\text { Relationship Quality }\end{array}$ & \multirow{3}{*}{ Future Collaboration } & & $\begin{array}{l}0.449 * * * \\
(8.16)\end{array}$ & 0.449 \\
\hline Relationship Trust & & $\begin{array}{l}-0.040 \\
(-0.44)\end{array}$ & $\begin{array}{l}0.162 * \\
(2.38)\end{array}$ & 0.122 \\
\hline $\begin{array}{c}\text { Retailer Satisfaction } \\
\text { with Brand } \\
\text { Manufacturer }\end{array}$ & & $\begin{array}{l}0.655^{* * *} \\
(8.85)\end{array}$ & & 0.655 \\
\hline
\end{tabular}

$$
{ }^{*} p<0.05 ;{ }^{* * *} p<0.001 \text {. }
$$

\subsection{Moderating Role of the Customer Expectation}

This study tests whether the degree of customer expectation of a brand will affect the relationship between retailer satisfaction with the brand manufacturer and future collaboration (H4). The sample was separated into two groups: low and high customer expectations with a brand. Arranging data from small to large, the first one-third includes respondents in the low group, and the last one-third is in the high group [50]. Again, an acceptable fit was found for the baseline model. The scores of $\chi^{2} / d f$, TLI, and CFI meet the suggested values. Table 10 presents the results of the tested models. The chi-square of Model 6 is compared to that of Model 4 , and $\Delta \chi^{2}$ equal to 7.17 and 3.13 at $1 d f$ are $p=0.007$ and $p=0.077$, respectively, thus $\mathrm{H} 5$ is supported. This indicates that $\mathrm{H} 4$ has a substantially stronger effect for one customer expectation with the brand group than the other does. A strong positive relationship exists between retailer satisfaction with the brand manufacturer and future collaboration for low customer expectation with the low group $(\beta=0.67, t=6.64)$ and a weak positive relationship for the high group $(\beta=0.36$, $t=5.18)$. The result of moderating effects indicates that customer expectation with the brand manufacturer moderates the relationship between retailer satisfaction with the brand manufacturer and future collaboration; therefore, H5 is supported. 
Table 10. Invariance Tests across Customer Expectation with Brand.

\begin{tabular}{|c|c|c|c|c|c|c|c|c|c|c|c|c|c|}
\hline \multirow[b]{2}{*}{ Model } & \multirow{2}{*}{$x^{2}$} & \multirow{2}{*}{$d f$} & \multirow{2}{*}{$\chi^{2} / d f$} & \multirow{2}{*}{ TLI } & \multirow{2}{*}{ CFI } & \multirow{2}{*}{$\begin{array}{l}\text { Nested } \\
\text { Models }\end{array}$} & \multirow{2}{*}{$\triangle x^{2}$} & \multirow{2}{*}{$\triangle d f$} & \multirow{2}{*}{$p$} & \multicolumn{2}{|c|}{$\begin{array}{c}\text { High Customer } \\
\text { Expectation }\end{array}$} & \multicolumn{2}{|c|}{$\begin{array}{l}\text { Low Customer } \\
\text { Expectation }\end{array}$} \\
\hline & & & & & & & & & & $\begin{array}{l}\text { Unstandard } \\
\text { Coefficient }\end{array}$ & $t$-Value & $\begin{array}{l}\text { Unstandard } \\
\text { Coefficient }\end{array}$ & $t$-Value \\
\hline 1. Base model (Model 1) & 314.276 & 122 & 2.576 & 0.875 & 0.902 & & & & & & & & \\
\hline 2. Equal loadings (Model 2) & 318.111 & 131 & 2.428 & 0.887 & 0.905 & $2-1$ & 3.835 & 9 & 0.922 & & & & \\
\hline $\begin{array}{l}\text { 3. Equal loadings, factor } \\
\text { intercorrelations (Model 3) }\end{array}$ & 319.685 & 132 & 2.422 & 0.887 & 0.905 & $3-2$ & 1.574 & 1 & 0.21 & & & & \\
\hline $\begin{array}{c}\text { 4. Equal loadings, } \\
\text { factor intercorrelations, } \\
\text { measurement error (Model 4) }\end{array}$ & 338.453 & 145 & 2.334 & 0.894 & 0.902 & $4-3$ & 18.768 & 13 & 0.13 & & & & \\
\hline $\begin{array}{c}\text { 5. Equal loadings, } \\
\text { factor intercorrelations, } \\
\text { measurement error, } \\
\text { structural coefficient } \\
\text { (Model 5) }\end{array}$ & 350.947 & 149 & 2.355 & 0.893 & 0.898 & $5-4$ & 12.494 & 4 & 0.014 & & & & \\
\hline $\begin{array}{l}\text { 6. Retailer satisfaction with } \\
\text { brand manufacturer } \rightarrow \\
\text { future collaboration } \\
\text { (Model 6) }\end{array}$ & 345.624 & 146 & 2.367 & 0.892 & 0.899 & $6-4$ & 7.172 & 1 & 0.007 & $0.36 *$ & 5.18 & $0.67 *$ & 6.64 \\
\hline
\end{tabular}




\section{Conclusions}

\subsection{Discussion}

This study uses the perspective of relationship quality within a business partnership to explore the path of technology products within distribution channels that result in satisfaction and the establishment of long-term working relationships. "Relationship quality" not only affects "retailer's satisfaction with the manufacturer" and "relational trust", but it guides profit generated by the synergy of the two and is a mediating element in future collaboration displayed by retailers. The most significant power created by their cooperation is the tangible and intangible resource produced through the transaction process between buyers and sellers. This cooperative value is maintained only through continuous transactions. If one party terminates the transaction, the cooperative value is nullified. This specific model is exemplified by situations wherein retailers have a specific ordering process that is unusable for other brands, or retailers contact specific manufacturers to increase communication efficiency. Services that bring advantages to specific brands ensure that retailers do not easily switch brands.

In addition, this study explores a new direction regarding loyalty in the form of how "customer impact" plays a role in future collaboration in the distribution channels of technological products. When customers love a specific brand and show "satisfaction" and "trust", they purchase products of that brand, making retailers more apt to work with the specific brand as customers bring direct and indirect effects on the achievement of value. Simultaneously, this proprietary asset between the brand manufacturer and customer can also attract customer attention and create future collaboration. For example, product knowledge and upgradeability of certain products are services tailored to the customer that affect the desire for cooperation and the future collaboration of retailers through brand value.

Originally, this study assumes that customer expectation will be a moderating factor between satisfaction and future cooperation, and the results demonstrate that high customer expectation has a smaller impact between "retailer's satisfaction with the manufacturer" and "future collaboration" than low customer expectation does. Therefore, this study deems customer impact as an interference factor, and the study results verified that the different levels of customer expectation would impact the desire of retailers to cooperate with manufacturers differently. Since customer expectations can be changed by the retailer's recommendations. As long as the manufacturers can give retailers better margins and support resources, customer expectations lower the effect of the retailer's satisfaction on future collaboration with the manufacturer. This study verifies that "relationship quality" will influence "relational trust" and "retailer's satisfaction with the manufacturer", and "relational trust" will also affect "retailer's satisfaction with the manufacturer". Moreover, the "retailer's satisfaction with the manufacturer" will influence "future collaboration". Out of accord with the debate, "relational trust" doesn't significantly influence "future collaboration". Relational trust affects future collaboration via retailer satisfaction with the brand manufacturer but not a direct influence.

\subsection{Theoretical Implications}

According to the research findings, this study provides implications for practice and academics as a reference, including theoretical and managerial implications. To achieve an optimal competitive position to stand out among numerous other brands, a corporation must examine the channel cooperation and sales process to solidify a long-term transactional relationship. Therefore, we first identified the elements affecting the future collaboration of technology product manufacturers and retailers. The four main elements in the conceptual framework are "relationship quality", "relational trust", "retailer's satisfaction with the manufacturer", and "future collaboration", and the moderating factor is "customer expectation".

The findings in this research provide some theoretical implications as academic references. The result is found that manufacturer-retailer relationship quality has a positive effect on relational trust, corresponding with the proposition of [6], which proves the 
importance of relationship quality within the channel relationship performance. The positive relationship between relational trust and retailer's satisfaction with the manufacturer conforms to [34] that consumer's perceptions of relational trust influence their satisfaction with the upstream manufacturer. The result that manufacturer-retailer relationship quality positively affects retailer's satisfaction with the manufacturer is in correspondence with [35] that relationship quality is an important variable for supply chain evaluation. The finding that a retailer's satisfaction with the manufacturer has a significant effect on future collaboration is consistent with the results indicated by [37]. Out of accord with [7], relational trust has an insignificant effect on future collaboration.

This research framework defines the future collaboration of the supply chain, which starts from the upstream-downstream relationship, and accordingly, the future collaboration possibility between manufacturers and retailers. Moreover, some supplement constructs linked with supply chain performance are proposed in this framework. Therefore, this framework not only generally assists the development of supply chain study but also helps specially develop the manufacture-retailer field. The framework in this research not only complements the related literature but also provides practical suggestions to marketers.

\subsection{Manegerial Implications}

This study investigated the interrelation between retailers and manufacturers. If two sides do not have a good relationship quality, the retailer will not be able to trust in manufacturer, and if transactions cannot be established on the basis of trust, it is impossible to have a long-term relationship of collaboration. If both sides boost the relationship quality to increase mutual trust, and then they can reduce the costs of operating procedures or management.

The following are discussions of the influential factors in the research study structure.

Manufacturer-retailer relationship quality and relational trust. Although retailers rely on manufacturer brands to provide products for achieving profit, the mutual trust between the two must be based on good relational quality. Consistent with the results proposed by [6], this study once again verifies the close relationship between relationship quality and relational trust. From practical experience, the manufacturer must carefully deliberate on the allocation of resource investment. They must strive to invest more resources in distributers, such as sales bonuses, personnel training, identification (providing company flags/store signs) and so on, to establish a relationship between the two, so two parties need to have a healthy relationship, then they can produce mutual trust, and be able to achieve goals together.

Relational trust and retailer's satisfaction with the manufacturer. When the retailer's satisfaction with the manufacturer is based on relational trust, the retail distributor's satisfaction with the brand manufacturer can increase. Thus the retail distributor focuses on the sale of a specific product from a manufacturer. Consistent with the results indicated by [34], this study concludes that relational trust influences overall satisfaction, and the positive correlation between relational trust and satisfaction is evident. A retailer's satisfaction must be based on mutual trust; with a low trust of the retailer, the retailer's satisfaction with the manufacturer is not enough. Therefore, in order to increase the mutual relational trust and investment by one party while increasing the positive thinking of both parties, retailers will request equal mutual investment. If both parties are willing to work with each other and see each other as partners, both parties will purposely establish relational trust to maintain a stable relationship and let each party understand that the mutual investment is to tie both parties to the cooperative relationship.

Manufacturer-retailer relationship quality and retailer's satisfaction with the manufacturer. This study found that the relationship quality has a positive impact on retailer's satisfaction with the manufacturer in correspondence with [35]. This study also verified that in situations of cooperation, the factor affecting satisfaction is not only relational trust but also the relationship quality. This shows that relational trust and relationship quality play 
a major role in overall satisfaction, and an increase in satisfaction benefits the focused sale of a manufacturer's products. This increased satisfaction requires mutual trust between the two parties to maintain a mechanism for cooperation.

Retailer's satisfaction with the manufacture and future collaboration. Manufacturers require channels to deliver products to customers, and retailers are the first in line in sales. The willingness of retailers to sell a brand's products critically affects the market share. "Retailer's satisfaction with the manufacture" has a positive effect on future collaboration, holding identical views as [37]. If a manufacturer cannot convince the majority of retailers to sell its products, then it loses the market. If satisfaction is flawed, they cannot plan a future long-term cooperative relationship. Although market characteristics and product selection are varied, the competition is endless. However, if retailers are able to identify the benefits and value of long-term loyalty, they will discover that manufacturers are willing to partake in a mutual investment of specific resources that perform better with loyalty. The results of this study verified the three influencing elements, "relationship quality", "relational trust", and "retailer's satisfaction with the manufacturer", which can be used as a reference by manufacturers to plan situations and avoid scenarios that can jeopardize future cooperation.

Moderating of customer expectations on the relationship between retailer's satisfaction with the manufacturer and future collaboration. This study also explored how the customer expectation element can affect retailers and manufacturers. This study revealed that the lower the customer expectation, the stronger the positive effect between the retailer's satisfaction with the brand supplier and future collaboration. This is because when customers have a lower expectation, retailers can provide appropriate advice based their experience on customer needs. Therefore, retailers will need more assistance in brand manufacture to recommend their products to customers, to sell the products as much as possible. It will increase the manufacturer invested cost; however, diligent management will let retailers feel more advantaged and be more confident in staying with the transaction relationship. The manufacturer will invest specific resources in the consumer, such as strong brand image creation, specific design or services related to products. Comparing to retailer's satisfaction with the manufacturer and future collaboration, supplier's support resources are more important for retailers. Even if the customer expectation is high, but retailers have lower satisfaction with the manufacturer, they are still willing to continue collaborating with the manufacturer in order to earn margins from the product.

According to this result, when based on relationship quality, relational trust, and satisfaction, retailers will find that the benefits of long-term cooperation between corporations produce far more benefits than short-term considerations. Considerations from the perspective of transaction cost show that maintaining relationship quality is an investment that has costs and is based on channel-personnel investing resources specific to cooperating partners, with considerations for long-term relationships. The effects of this method can only be produced through continuous transactions with specific manufacturers. Once the transfer is made to another manufacturer, all invested resources lose value and the cost of transfer increases. In other words, the party that invests resources will have difficulty leaving and is entrenched in this transaction relationship. The establishment of certain specific resources is intangible, such as a deep-rooted psychological acknowledgment, which will subconsciously be a critical influence. Therefore, investing resources by the manufacturer has value, but it is simultaneously an entrenched cost, which leaves the investing party feeling that it cannot easily change transaction partners. Thus, when the cost of invested resources rises, it is more likely to keep transaction partners and ensure high loyalty for future collaboration.

\subsection{Research Limitations and Further Research}

This study is based on the distribution of technology products in Taiwan, and the regional characteristics of the distribution channel are strong. Results may differ according to national habits, commercial operations, law, and culture. When the focus is on global 
markets, other environmental and cultural factors that may produce effects must be considered. For example, South Korea's Samsung Co. enjoys strong brand loyalty because of the local customers' strong sentiments toward its own national products. Their emphasis on "managing each country's local market" fully explains the local characteristics of a channel. Therefore, each aspect in the overall model in this study and their weight and relationship strength differ among regions and market characteristics. In addition, future studies can also examine corporate brand reputation as a moderate variable in the model, allowing the study to provide results that differ from standard papers in terms of relationship quality and how it affects satisfaction, and then affects future collaboration. Finally, this research utilized a unidimensional construct of three items to measure relationship quality. The authors of [52] mentioned that this construct had been conceptualized as a multidimensional construct composed of three dimensions: trust, commitment, and satisfaction, which deserves to be adopted in future research.

Author Contributions: Conceptualization, S.-L.C. and H.-H.T.; methodology, S.-L.C.; software, H.-H.T.; validation, S.-L.C. and Y.-H.L.; formal analysis, S.-L.C.; investigation, H.-H.T.; resources, H.-H.T.; data curation, Y.-H.L.; writing—original draft preparation, H.-H.T.; writing-review and editing, S.-L.C. and Y.-H.L.; visualization, Y.-H.L.; supervision, S.-L.C.; project administration, S.-L.C. All authors have read and agreed to the published version of the manuscript.

Funding: This research received no external funding.

Data Availability Statement: Not applicable.

Conflicts of Interest: The authors declare no conflict of interest.

\section{References}

1. Holweg, M.; Disney, S.; Holmström, J.; Småros, J. Supply chain collaboration: Making sense of the strategy continuum. Eur. Manag. J. 2005, 23, 170-181. [CrossRef]

2. Trada, S.; Goyal, V. Tripartite role of communications in channel relationships: Mitigating exchange hazards, reducing opportunism, and curtailing its ill effects on relationship performance. Ind. Mark. Manag. 2020, 85, 281-294. [CrossRef]

3. Lazzarini, S.G.; Claro, D.P.; Mesquita, L.F. Buyer-Supplier and Supplier-Supplier Alliances: Do They Reinforce or Undermine One Another? J. Manag. Stud. 2008, 45, 561-584. [CrossRef]

4. Coughlan, A.T.; Anderson, E.; Stern, L.W.; El-Ansary, A.I. Marketing Channels; Prentice Hall: Englewood Cliffs, NJ, USA, 1992.

5. Ha, J.; Jang, S.S. Perceived justice in service recovery and behavioral intentions: The role of relationship quality. Int. J. Hosp. Manag. 2009, 28, 319-327. [CrossRef]

6. Dwyer, F.R.; Schurr, P.H.; Oh, S. Developing Buyer-Seller Relationships. Econ. Psychol. 2005, 51, 11-27.

7. Morgan, R.M.; Hunt, S.D. The commitment-trust theory of relationship marketing. J. Mark. 1994, 58, 20-38. [CrossRef]

8. Wisker, Z.L. Examining relationship quality in e-tailing experiences: A moderated mediated model. Mark. Intell. Plan. 2020, 38, 863-876. [CrossRef]

9. Naudé, P.; Buttle, F. Assessing Relationship Quality. Ind. Mark. Manag. 2000, 29, 351-361. [CrossRef]

10. Li, G. The impact of supply chain relationship quality on knowledge sharing and innovation performance: Evidence from Chinese manufacturing industry. J. Bus. Ind. Mark. 2020, 36, 834-848. [CrossRef]

11. Moorman, C.; Zaltman, G.; Deshpande, R. Relationships Between Providers and Users of Market Research: The Dynamics of Trust Within and Between Organizations. J. Mark. Res. 1992, 29, 314-328. [CrossRef]

12. Parra-Requena, G.; Ruiz-Ortega, M.J.; Garcia-Villaverde, P.M.; Ramírez, F.J. Innovativeness and performance: The joint effect of relational trust and combinative capability. Eur. J. Innov. Manag. 2020, in press. [CrossRef]

13. Blau, P.M. Exchange and Power in Social Life; John Wiley \& Sons Inc.: New York, NY, USA, 1964.

14. Mungra, Y.; Yadav, P.K. The mediating effect of satisfaction on trust-commitment and relational outcomes in manufacturersupplier relationship. J. Bus. Ind. Mark. 2020, 35, 219-230. [CrossRef]

15. Aulakh, P.S.; Kotabe, M.; Sahay, A. Trust and Performance in Cross-Border Marketing Partnerships: A Behavioral Approach. J. Int. Bus. Stud. 1996, 27, 105-113. [CrossRef]

16. Oliver, R.L. Satisfaction: A Behavioral Perspective on the Consumer; McGraw-Hill/Richard D. Irwin: New York, NY, USA, 1997.

17. Piancatelli, C.; Massi, M.; Vocino, A. The role of atmosphere in Italian museums: Effects on brand perceptions and visitor behavioral intentions. J. Strateg. Mark. 2020. [CrossRef]

18. Rojas, C.D.; Camarero, C. Visitors' experience, mood and satisfaction in a heritage context: Evidence from an interpretation center. Tour. Manag. 2008, 29, 525-537. [CrossRef]

19. Friedman, S.R.; Reynolds, J.; Quan, M.A.; Call, S.; Crusto, C.A.; Kaufman, J.S. Measuring changes in interagency collaboration: An examination of the Bridgeport Safe Start Initiative. Eval. Program Plan. 2007, 30, 294-306. [CrossRef] 
20. Maitland, I.; Bryson, J.; Ven, A.V.D. Sociologists, economists, and opportunism. Acad. Manag. Rev. 1985, 10, 59-65. [CrossRef]

21. Das, T.K.; Teng, B.S. Between Trust and Control: Developing Confidence in Partner Cooperation in Alliances. Acad. Manag. Rev. 1998, 23, 491-512. [CrossRef]

22. Teece, D.J. Competition, cooperation, and innovation: Organizational arrangements for regimes of rapid technological progress. J. Econ. Behav. Organ. 1992, 18, 1-25. [CrossRef]

23. Ford, C.R.; Henderson, J.; Handley, D.M. Enhancing long-term care for older adults: An exploration of interagency collaboration within geriatric education centers. J. Health Hum. Serv. Adm. 2010, 32, 447-485.

24. Tsenga, S.H.; Liub, K.; Wanga, W.L. Moving toward being analytical: A framework to evaluate the impact of influential factors on interagency collaboration. Child. Youth Serv. Rev. 2011, 33, 798-803. [CrossRef]

25. Sheth, J.N. A Model of Industrial Buyer Behavior. J. Mark. 1973, 37, 50-56. [CrossRef]

26. Olson, J.C.; Dover, P.A. Disconfirmation of consumer expectations through product trial. J. Appl. Psychol. 1979, 64, 179-189. [CrossRef]

27. Cronin, J.J.; Morris, M.H. Satisfying Customer Expectations: The Effect on Conflict and Repurchase Intentions in Industrial Marketing Channels. J. Acad. Mark. Sci. 1989, 17, 41-49. [CrossRef]

28. Anderson, P.F.; Chambers, T.M. A Reward/Measurement Model of Organizational Buying Behavior. J. Mark. 1985, 49, 7-23. [CrossRef]

29. Calvert, P.J. International Variations in Measuring Customer Expectations. Libr. Trends 2001, 49, 732-757.

30. Parasuraman, A.; Zcithaml, V.; Berry, L. SERVQUAL: A Multiple-Item Scale for Measuring Consumer Perceptions of Service Quality. J. Retail. 1988, 64, 12-40.

31. Couch, L.L.; Jones, W.H. Measuring levels of trust. J. Res. Personal. 1997, 31, 319-336. [CrossRef]

32. Arifin, J.; Abu Bakar, N.; Ghazali, P.L.; Remli, N.; Muhammad, H. The Role of Satisfaction in Mediating Trust, Commitment and Loyalty in family Takaful. J. Manag. Theory Pract. 2020, 1, 28-34.

33. Wagner, S.M.; Eggert, A.; Lindemann, E. Creating and appropriating value in collaborative relationships. J. Bus. Res. 2010, 63, 840-848. [CrossRef]

34. Abubakar, M.M.; Mokhtar, S.S.; Abdullattef, A.O. The Role of Long-Term Orientation and Service Recovery on the Relationships between Trust, Bonding, Customer Satisfaction and Customer Loyalty. Asian Soc. Sci. 2014, 10, $209-220$.

35. Nguyen, D.T.; Pham, V.T.; Tran, D.M.; Pham, D.B.T. Impact of Service Quality, Customer Satisfaction and Switching Costs on Customer Loyalty. J. Asian Financ. Econ. Bus. 2020, 7, 395-405. [CrossRef]

36. Alghurair, S.; Simpson, S.; Guirguis, L. What elements of the patient-pharmacist relationship are associated with patient satisfaction? Patient Prefer. Adherence 2012, 6, 663-676. [PubMed]

37. Svensson, G.; Mysen, T.; Payan, J. Balancing the sequential logic of quality constructs in manufacturing-supplier relationshipsCauses and outcomes. J. Bus. Res. 2010, 63, 1209-1214. [CrossRef]

38. Nilsson Purchasing by Swedish grocery chains. Ind. Mark. Manag. 1977, 6, 317-328. [CrossRef]

39. Lai, K.H.; Bao, Y.; Li, X. Channel relationship and business uncertainty: Evidence from the Hong Kong market. Ind. Mark. Manag. 2008, 37, 713-724. [CrossRef]

40. Cannon, J.P.; Perreault, W.D., Jr. Buyer-seller relationships in business markets. J. Mark. Res. 1999, 36, 436-460.

41. Glynn, M.S. The moderating effect of brand strength in manufacturer-retailer relationships. Ind. Mark. Manag. 2010, 39, 1226-1233. [CrossRef]

42. Conway, J.M.; Lance, C.E. What reviewers should expect from authors regarding common method bias in organizational research. J. Bus. Psychol. 2010, 25, 325-334. [CrossRef]

43. Lindell, M.K.; Whitney, D.J. Accounting for common method variance in cross-sectional research designs. J. Appl. Psychol. 2001, 86, 114-121. [CrossRef]

44. Chen, L.S.-L.; Chen, J.-H. Antecedents and optimal industrial customers on cloud services adoption. Serv. Ind. J. 2021, 41, 606-632. [CrossRef]

45. Huang, S.Y. Relevance of IT integration into teaching to learning satisfaction and learning effectiveness. World J. Educ. 2014, 4, 1. [CrossRef]

46. Bagozzi, R.P.; Yi, Y. On the Evaluation of Structural Equation Models. Acad. Mark. Sci. 1988, 16, 76-94. [CrossRef]

47. Nunnally, J.C.; Bernstein, I.H.; Berge, J.M.F. Psychometric Theory; McGraw-Hill: New York, NY, USA, 1967.

48. Fornell, C.; David, F. Evaluating structural equation models with unobservable variables and measurement error. J. Mark. Res. 1981, 18, 39-50. [CrossRef]

49. Anderson, J.C.; Gerbing, D.W. Structural equation modeling in practice: A review and recommended two-step approach. Psychol. Bull. 1988, 103, 411-423. [CrossRef]

50. Hair, J.F.; Black, W.C.; Babin, B.J.; Anderson, R.E. Multivariate Data Analysis; Pearson Education Inc.: Pearson, NJ, USA, 2010.

51. Hu, L.T.; Bentler, P.M. Cutoff criteria for fit indexes in covariance structure analysis: Conventional criteria versus new alternatives. Struct. Equ. Model. 1999, 6, 1-55. [CrossRef]

52. Palmatier, R.W.; Dant, R.P.; Grewal, D.; Evans, K.R. Factors influencing the effectiveness of relationship marketing: A ma-analysis. J. Mark. 2006, 70, 136-153. [CrossRef] 